This is an electronic reprint of the original article. This reprint may differ from the original in pagination and typographic detail.

Author(s): Kokkonen, Lotta; Almonkari, Merja

Title: Teaching networking: an interpersonal communication competence perspective

Year: $\quad 2015$

Version:

Please cite the original version:

Kokkonen, L., \& Almonkari, M. (2015). Teaching networking: an interpersonal communication competence perspective. In J. Jalkanen, E. Jokinen, \& P. Taalas (Eds.), Voices of pedagogical development : expanding, enhancing and exploring higher education language learning (pp. 31-56). Research-publishing.net.

https://doi.org/10.14705/rpnet.2015.000286

All material supplied via JYX is protected by copyright and other intellectual property rights, and duplication or sale of all or part of any of the repository collections is not permitted, except that material may be duplicated by you for your research use or educational purposes in electronic or print form. You must obtain permission for any other use. Electronic or print copies may not be offered, whether for sale or otherwise to anyone who is not an authorised user. 


\section{Teaching networking: an interpersonal communication competence perspective}

\section{Lotta Kokkonen $^{1}$ and Merja Almonkari}

\section{Abstract}

$\mathrm{M}$

odern working life calls for competences that enable people to be creative, innovative and effective. Studies looking at contemporary enterprises and organisations such as businesses and schools have shown that many of the qualifications that graduating students would need, including informal learning (see Gielen, Hoeve \& Nieuwenhuis 2003), innovativeness (e.g. Moolenaar \& Sleegers 2010; Obstfeld 2005) and creativity (e.g. Burt 2004; Perry-Smith \& Shalley 2003), are associated with interpersonal relationships and social networks. According to a report on the national career survey (EK 2011a), effective networking is dependent on social skills such as the ability to establish contacts in multicultural environments, the ability to discuss with others, understanding the perspectives of others and listening skills. For speech communication teachers and researchers, those skills listed above are communication skills, and more precisely, interpersonal communication skills. In this article, social networks are perceived from a perspective of interpersonal communication and networking is viewed as interpersonal communication competence. To date, the talents, characteristics and skills which people need when networking have not been consistently described from the perspective of interpersonal communication competence. Because it is possible to enhance this competence, we argue that networking is something that students could, and should, learn at the higher education level.

Keyword: networking, interpersonal communication competence, teaching communication, higher education.

1. Language Centre, University of Jyväskylä, Finland; lotta.o.kokkonen@jyu.fi

2. Language Centre, University of Jyväskylä, Finland; merja.almonkari@jyu.fi

How to cite this chapter: Kokkonen, L., \& Almonkari, M. (2015). Teaching networking: an interpersonal communication competence perspective. In J. Jalkanen, E. Jokinen, \& P. Taalas (Eds), Voices of pedagogical development - Expanding, enhancing and exploring higher education language learning (pp. 31-56). Dublin: Research-publishing.net. doi:10.14705/rpnet.2015.000286 


\section{Introduction}

Puhakka, Rautopuro and Tuominen (2010) discuss employability among Finnish university graduates. They found that the most needed skills and forms of knowledge for graduates entering today's job market are interpersonal skills and academic skills. Interpersonal skills included negotiation skills, teamwork and social skills, organisation and coordination skills, and communication skills in Finnish (see also EK 2011b). Since the Bologna process, which defines employability as "the ability to gain initial employment, maintain employment, and to be able to move around within the labour market", universities have become more aware that they have to ensure graduates obtain the skills and knowledge that make them employable (Puhakka et al. 2010).

Changes in modern working life have created new kinds of needs for communication competence. Employees will have to deal with globalisation, internationalisation, and the rapid development of technology. The development of organisation models that rely heavily on computer-mediated communication involving people from different parts of the world dealing with increasingly abstract elements represent just a few of the aspects that have enhanced the need for communication competence at work. It is anticipated that the significance of one's communication competence is going to be even greater in the future working life (Aalto, Ahokas \& Kuosa 2008; "FinnSight 2015" 2006; Huotari, Hurme \& Valkonen 2005; Linturi 2007).

One of the communication requirements of modern working life includes the ability to create and maintain interpersonal relationships. For example, multinational cooperation and teamwork as well as the development of creative and innovative projects call for interpersonal relationships and social networks consisting of those relationships. Expertise is no longer something that an individual can create and enhance alone, but rather it is an ability to create a team and a community in which each individual's personal areas of expertise complement the knowledge and skills of others. Indeed, the Confederation of

3. Retrieved from http://www.ehea.info/article-details.aspx?ArticleId=16 
Finnish Industries (EK 2011a) $)^{4}$ has concluded in their report that networking is one of the key skills and qualifications required in the future job market.

In this article, social networks are seen as being constructed by and maintained within the interpersonal relationships that people have. Taking into consideration what is being said about the future working life, we address the question of whether interpersonal competence should be taught as part of communication and language courses at the university level, and raise the question of whether interpersonal competence is indeed already being taught on university-level communication and language courses and how this instruction could be developed further to benefit graduating students who are preparing themselves for future employment.

In many studies and reports on the current and possible future requirements for employees, the communication competence needed in working life is emphasised (Gaboury 1999; Himanen 2004; Kostiainen 2003; Lang, Cruse, McVey \& McMasters 1999; Morreale, Osborn \& Pearson 2000; Pyöriä 2006). It seems that communication competence is one of the key factors influencing wellbeing at work and the success of both individuals and organisations alike. Regardless of the vast amount of research that supports the claim that communication training is important, there is not much research specifying the types of communication skills that might be most appropriately incorporated in the curricula of particular fields. For example, Darling and Dannels (2003: 3-4) studied communication skills needed in engineering and they point out that, not much is known "about what kinds of communication tasks practicing engineers face (e.g. team presentations, one-on-one meetings with employees, formal PowerPoint presentations), the typical audiences for whom those speaking tasks occur (e.g. clients, employees, public forums, the government), and the perceived consequences of these speaking tasks for workplace success". Since 2003, there have been some attempts to look at work-related interpersonal communication skills and the communication competences needed in workrelated interpersonal relationships. The question of whether this knowledge and 
information has reached the higher education communication training offered on university language centre courses will be addressed in this article.

This article first provides a brief overview of social networks and the interpersonal communication perspective on them. It then goes on to look at what kind of interpersonal skills and competences are related to networking, and what we know about learning these things. Finally, we examine the possibilities and challenges of teaching networking and interpersonal communication competence in a higher educational setting and some directions for future research are proposed.

\section{Social networks as the focus and goal of learning}

Social networks are everywhere. The ubiquity of networks in contemporary political and economic life, networking and interactivity seem to be a part of our everyday life. Network thinking is so broadly applied that authors such as Castells $(1996,2000)$ have started to talk about 'the network society'. Networks as a metaphor and model of individual and collective life seem to dominate contemporary Western thinking (Barry 2001; Riles 2000). Network theory and theories of networks have enabled researchers to analyse not only the chains within social networks, but also to find explanations to various phenomena in human social life (Frankham 2006; Gould 2003; Riles 2000; Trevillion 2000).

Indeed, network theory and related theories have become extremely popular in various fields and "The network approach spans a broad range of disciplines, including sociology, social psychology, mathematics, political science, communication, anthropology, economics, and epidemiology" (Katz, Lazer, Arrow \& Contractor 2004: 311; see also Newman, Barabási \& Watts 2006). As Borgatti and Halgin (2011) point out, the term social network is applied to almost everything from a trade associations to listservs and social media websites, while the number of studies on social networks has increased dramatically in recent decades. 
Overall, social networks can be seen as method, metaphor and form (see Knox, Savage \& Harvey 2006) and social network analysis is seen as a method or a perspective that is applied to great number of areas. Trevillion (2000: 514) points out that " $[\mathrm{w}]$ hereas network analysis is one among many specific methodologies available to social scientists including social work research, the social network approach is much broader and is best seen as an orientation to the social world which attempts to understand it in terms of sets, patterns and linkages".

Generally, social networks are said to consist of a set of actors and relations between these actors. In the human sciences, actors, also called nodes, can be individuals, groups, organisations or societies depending on the approach and perspective (see Katz et al. 2004). The relations, also called ties or edges, between the actors can be information flows, economic exchange and ties that provide social support to the actors in question. These social networks can also be defined simply as "interconnected individuals who are linked by patterned communication flows" (Rogers \& Kincaid 1981: 82).

If one considers the myriad approaches, theoretical considerations and methodologies, it is understandable that there is no single formal statement of the network perspective, nor is there a single network theory that could be applied everywhere. In this article we see that social networks, also called interpersonal networks, communication networks and personal communities, are constructed by the interpersonal relationships that a person has. We use the term social network, but wish to stress that within these networks of interpersonal relationships communication is not only seen as a flow between the actors. Instead, interpersonal relationships are initiated and maintained through communication. Communication is therefore a fundamental and inseparable element within these relationships and social networks.

We use the term interpersonal relationships when referring to the relations between individuals. When defining an interpersonal relationship, we rely on what Wilmot (1996) has said about the nature of these relationships. He points out that partners need to be aware of the other and of the relationship for it to exist (see also Neuliep 1996). Furthermore, interpersonal relationships are 
seen as a process in which meanings are constantly negotiated in relation to shared history, the present and the anticipated future. What we mean by this is that interpersonal relationships are being initiated and maintained through communication and their qualities and meanings are negotiated in interaction between partners and over a period of time (Littlejohn 2002; Sigman 1998). Consequently, networking is seen as developing and maintaining interpersonal relationships.

\section{The benefits of networking and why we should teach it}

Numerous studies on social networks make clear the reasons why social networks are such a relevant phenomenon and why higher education graduates should know about them. Furthermore, they make a case for why graduates should have the skills to develop and maintain social networks.

Within the human sciences, it seems to be a common belief that networking is beneficial and recommended to individuals, organisations and companies alike. For example, in management research social networks are being discussed in relation with creativity (Burt 2004; Perry-Smith \& Shalley 2003), informal learning (Gielen et al. 2003), innovation (Obstfeld 2005), and job performance (Sparrowe, Liden, Wayne \& Kraimer 2001), among many others (see also Borgatti \& Halgin 2011).

Benefits and positive outcomes related to social networks include social support (see Mitchell \& Trickett 1980) and the health outcomes related to social networks have been discussed widely (see Albrecht \& Goldsmith 2003). Furthermore, the importance of social networks can also be linked to adaptation to a life change (Mitchell \& Trickett 1980), as well as to integration and belonging to a new cultural environment. These studies show that social networks and individuals' interpersonal relationships can be seen as the glue that ties a person to a group, a community, a physical environment or even a society (see Kokkonen 2010). 
Communication studies looking at social networks have often dealt with questions such as what groups of people there are in an individual's networks (e.g. relatives, friends, acquaintances), what kinds of relationships there are within the networks (weak or close relationships), and what kinds of resources these networks, or different relationships within networks, provide to a person (Wellman 2007). Studies have often focused on the size or density of the network (Mitchell \& Trickett 1980) and modern technology has further multiplied the possibilities to research these aspects. Since their introduction, social network sites such as Facebook have attracted millions of users, many of whom have integrated these sites into their daily practices. Contemporary technology enables researchers to look at the thousands, even millions of connections and relationships people have (Boyd \& Ellison 2007). Consequently, many recent studies on social networks and network sites are nowadays published in channels such as the Journal of Computer-Mediated Communication.

Another network characteristic commonly studied in the field of communication is the degree of connections, that is, the average number of relationships that each member has with other members of the network. Furthermore, social networks have also been studied by looking at the intensity, durability, multidimensionality, directness and reciprocity of those linkages. Relationship dispersion, frequency and homogeneity are among the other characteristics of social networks that have been studied (Mitchell \& Trickett 1980).

The benefits of social networks seem to be well addressed and, indeed, the question of why people create, maintain, dissolve and reconstitute network ties has been explained by multiple schools of thought or groups of theories (for analyses of existing theories, see Monge \& Contractor 2003). Discussing networking and networks in general with students is beneficial not only in terms of their enhanced networking competence. The benefits might be even more extensive and, as Alatarvas (2013) has stated, understanding social networks and network processes in general would benefit people when developing social technologies in the future. Furthermore, Alatarvas (2013) suggests a deeper understanding of networks and network processes will support the understanding of different invasive phenomena, from gossip to infectious diseases. As all of 
these studies suggest, an understanding of social networks is, on numerous levels, highly relevant for modern working life.

\section{Networking and interpersonal communication competence}

A number of studies have examined networking as a skill or set of skills or as a competence. In contemporary research, terms such as networking competence or simply networking are frequently used (see Ritter \& Gemünden 2003). Network competence has been described as the ability of an individual or the relationship of individuals or as an ability of organisations (e.g. Mittilä 2006; Thornton, Henneberg \& Naudé 2013).

Little is said, however, about network competence from an individual or interpersonal perspective. Leskinen (2011) is among the few who have adopted an individual's point of view when researching entrepreneurial networking process. Her case study included an entrepreneurial networking project involving 25 firms operating in the service market, and the results revealed that the key elements in the entrepreneurial networking process are dialogue, trust and commitment. The practices and routines that are based on good and respectful dialogue encouraged partners in innovative discussions, creativeness and cooperation as well as in developing new services. Entrepreneurs received support and encouragement from other entrepreneurs in their network, and their relationships and cooperation in networks generated new business possibilities and channels. Networking also helped them cope with the various challenges entrepreneurs face.

In addition to Leskinen's (2011) study, Purhonen (2008, 2012) has explored networking from a communication and interpersonal communication perspective. She looked at the interpersonal communication competence from the perspective of small and medium-sized enterprises in the contexts of networking and business collaboration (Purhonen 2008). In her results, Purhonen (2008: n. p.) lists "information sharing, the management of diversity, adaptation and adjustment, 
integrative negotiation, and the creation and management of relationships" as focal areas of interpersonal communication competence in the networking and collaboration of SME during an internationalisation process. In the context of collaboration and networking, the key criteria for competent information sharing are mutuality, reciprocity and openness (Purhonen 2008). Based on the given criteria and considering that the broader networks of the involved parties are also closely connected, it seems to be useful for the cooperating parties to be aware of the larger social networks of their partners. This enables them to determine the sources, such as knowledge and skills that could be available for them too. "For SME owners, managers and employees it is thus important to recognize what kind of information and other resources exist within their interpersonal networks, and how these resources could help their collaborating group or partners", Purhonen (2008: n. p.) concludes.

While discussing the creation and management of relationships, Purhonen (2008) refers to lists of communication skills or behaviours that could be considered broadly as relational communication skills. Also other researchers have discussed this issue and they have listed skills such as showing concern for others, reasoning with others, expressing trust, elaborating, directness and mutual concessions, and providing face support (Hardy, Phillips \& Lawrence 2003; Hargie \& Tourish 1997; Purhonen 2008) as relational skills.

Since networking is, in this article, seen as developing and maintaining interpersonal relationships, and because there are so few studies analysing it from this perspective, we will briefly look into what has been said about interpersonal communication competence in contemporary working life in general.

\section{Interpersonal communication competence for working life}

In communication research on interpersonal communication, the foundation of competence often relies on ideas from Spitzberg and Cupach (1984). Communication competence in general can be defined "as an impression of 
appropriateness and effectiveness, which is functionally related to individual motivation, knowledge, skills, and contextual facilitators and constraints" (Spitzberg 2013: 126). Along the same lines, Purhonen and Valkonen (2013: n. p.) have defined interpersonal communication competence by using Valkonen's definition from 2003 as "knowledge about effective and appropriate interpersonal communication, motivation to engage in social interaction, meta-cognitive communication skills, as well as the interpersonal communication skills needed to act in a way that the interactants perceive to be both effective and appropriate" (Valkonen 2003: 26).

Interpersonal communication competence is understood as "construction of cognitive, affective and behavioural dimensions. The cognitive dimension refers to knowledge and metacognitive skills [...] such as knowledge of the communication partner of conversing and the topic", communication processes, strategies and context (Purhonen 2008: n. p.). Metacognitive skills include planning, perceiving, evaluating, controlling and analysing communication (Spitzberg 2000, 2003; Valkonen 2003).

Furthermore, interpersonal communication competence can be seen as an influence or impression formed by interaction partners about each other's communication behaviour. The impression can be formed by an observer about a participant's behaviour (Lakey \& Canary 2002; Spitzberg 2000). Spitzberg (2013) has also discussed interpersonal communication competence as evaluations attributed and formed on the basis of how effective and appropriate communication behaviour is perceived to be, rather than considering it to be a certain set of skills, abilities or tactics.

Context also affects interpersonal communication competence, because interaction always takes place in a certain culture, time, relationship, situation and function. This context influences as well as gets incorporated into both actions and judgments of actions. Communication skills, for example, are evaluated differently in different contexts. The participants' and observers' perception of the context determines the expectations for interpersonal communication competence (Spitzberg 2000, 2013). It is therefore relevant to also look at the 
interpersonal communication competence needed in different professions and professional contexts.

Recent research has focused on the communication competence requirements for a range of professions (see Frymier \& Houser 2000 on teachers, Darling \& Dannels 2003 on engineers, Rouhiainen-Neuenhäuserer 2009 on managers, AlaKortesmaa \& Välikoski 2008 on judges, and Laajalahti 2014 on researchers). Studies have also been interested in the educational methodologies and contexts used for teaching interpersonal competence in, for example, a healthcare context (Koponen 2012), among pharmacists (Hyvärinen 2011) and among accountants (Gray 2010).

As an example, Laajalahti's (2014) study focused on researchers' experiences and understanding of the need for interpersonal competence and learning interpersonal competence at work. In the study, researchers reported having work-related interpersonal relationships with at least 16 different groups of people. These included relationships with other researchers, students, professors and other academic professionals, participants in their studies, possible clients, officials and media representatives, among many others. According to these researchers, communication competence affected their personal career development, publications, funding and other resources, and job opportunities. Belonging to the academic community was also reported to be dependent on respondents' interpersonal communication competence. In addition, the research work itself was influenced by the communication competence of the researcher. For example, publicising the work, its societal relevance, the applicability of the results as well as their reliability and validity were all dependent on the researcher's interpersonal communication competence (Laajalahti 2014).

In Frymier and Houser's (2000) study of communication skills within teacherstudent interpersonal relationships, they applied an interpersonal competence tool developed by Burleson and Samter (1990) for measuring interpersonal relationships. The tool, adapted to measure specific communication skills in a given context, included eight elements: 
"conversational skill (the ability to initiate, maintain, and terminate enjoyable casual conversations), referential skill (the ability to convey information clearly and unambiguously), ego supportive skill (the ability to make another feel good about himself or herself), comforting skill (the ability to make others feel better when depressed, sad, or upset), conflict management (the ability to reach mutually satisfying solutions in conflicts), persuasive skill (the ability to get people to modify their thoughts and behaviours), narrative skill (the ability to entertain through jokes, gossip, stories, etc), and regulation (the ability to help someone who has violated a norm to fix the mistake effectively)" (Frymier \& Houser 2000: 208).

In their study, Frymier and Houser (2000) found that these methods for measuring communication skills within friendships are also applicable in teacher-student relationships. Whether the model is applicable to professional relationships such as those between managers and employees or collegial relationships between co-workers is still a question mark and requires more empirical research.

In summary, the skills mentioned earlier in the various networking contexts include information sharing, integrative negotiation, respectful dialogue, as well as "showing concern for others, reasoning with others, expressions of trust, using elaboration, directness and mutual concessions and providing support for others" (Purhonen 2008: n. p.). All of these skills are basic interpersonal communication skills. Similar sets of skills are highlighted in many other contexts as well (see Hargie \& Dickson 2004; Spitzberg 2013).

All the examples mentioned above provide relevant information about interpersonal communication competence in working life. Yet, as Laajalahti (2007: 335) concludes in her article about the development of interpersonal communication competence at work, there have been many attempts to "define the interpersonal communication competence needed in current working life or in specific professions, but many of these [result in fragmented] lists of requirements" (see also Kostiainen 2003). Instead of listing all the different 
possible forms of interpersonal communication competence and skills, this section has introduced its key aspects. In the following section we discuss if it is possible to teach any of interpersonal competence in a higher educational context.

\section{Teaching networking: interpersonal competence as a target for teaching and learning}

Despite many studies, there still exists a widely held belief about networking and interpersonal communication skills that they are like personality traits: inborn and not possible to learn. In this section of our article we discuss the possibilities and challenges of teaching networking and interpersonal communication competence in a higher educational setting. The discussion is based on the assumption that, like any communication skill, interpersonal communication competence can also be taught, enhanced and learned in formal educational settings.

The idea of interpersonal communication competence being something that one can learn and something that can be taught is widely accepted. The learning process contains many stages, for example observation, emulation, self-control and self-regulation. Skilled behaviour improves with practice and feedback (for more on skilled interpersonal communication, see Hargie \& Dickson 2004). As Laajalahti (2007: 341) mentioned "communication scholars disagree about how much interpersonal communication competence can change over time, the general idea that it can develop and be developed is widely accepted" (see also Greene 2003; Hargie \& Dickson 2004).

In this article we are interested in the training provided to students entering working life. We know that the majority of significant learning experiences seem to take place in informal learning (Merriam \& Clark 1993). Furthermore, we know that interpersonal communication competence is often acquired through informal learning (Segrin \& Givertz 2003). However, like Puhakka, Rautopuro and Tuominen (2010: 45) point out "employers want graduates 
who are well prepared for the world of work". Thus, we argue that enhancing students' interpersonal communication competence prior to entering working life would give them certain advantages in the job market.

Development of language and communication skills in infancy and childhood have drawn more attention within the field of communications and further research is needed in order to develop theoretical and empirical methods for exploring the development of interpersonal communication competence at work (Laajalahti 2007). Comprehensive reviews of communication training, let alone of interpersonal communication training, in higher educational institutions is difficult to find.

However, studies conducted in specific areas such as healthcare and education do exist. For example communication skills training in healthcare teaching in pre-registration nurse education were reviewed in the United Kingdom in the early 2000s (Chant et al. 2002; see also Hargie, Boohan, McCoy \& Murphy 2010). The results show that methods used in communication skills training included experiential methods, use of standardised patients, videos, lectures, groupwork and drama workshops, role-play, group discussion, readings, and audiovisual methods. Skills identified as being facilitated and evaluated in communication skills training in the UK nurse training programmes include empathy, anti-stereotyping practices, self-awareness, interviewing skills and critical thinking (Chant et al. 2002).

In Finland, Hyvärinen (2011) studied interpersonal communication competence in the field of pharmacy. Her results show that professional communication competence is connected to students' knowledge of their own field and to students' knowledge of interpersonal communication. Practical training in real work situations, constructive feedback, the role of mentors and communication between mentors and students were central in learning interpersonal communication competence (Hyvärinen 2011).

Another example from the Finnish context is a study by Koponen (2012) in which she compared Finnish medical students' perceptions of the suitability 
of three experiential methods in learning interpersonal communication competence. The students' self-reported learning outcomes included becoming aware of interpersonal communication competence, knowledge of professional communication and patient-centeredness. The students' own attitudes to learning communication skills became more positive (Koponen 2012).

In speech communication, interpersonal communication competence consists of more than skills; it also addresses motivational and ethical considerations. This is not to say that interaction skills do not have an important role in interpersonal competence. On the contrary, Spitzberg (2013: 131) suggests that

"to be competent, an interactant needs have the motivation to create a competent impression, and avoid being debilitated by anxiety. Further, an interactant needs to have the knowledge relevant to the context, topics, activity procedures, norms, and the like. Having motivation and knowledge, however, may not be sufficient if the person cannot demonstrate the actual interaction skills required to implement their goals and understandings".

As a consequence, the focus of teaching and learning interpersonal communication has shifted from situation-specific behaviour and skills to broader dimensions. In particular, the importance of knowledge has increased. Teaching knowledge of communication processes is relevant, for example, in planning interaction (Isotalus 2006, Isotalus \& Mäki 2009).

Communication teaching methods are often diverse, and formal learning of interpersonal communication competence, provided in the Finnish context by trained teachers of speech communication, is usually based on activities within a structured learning setting (see Gerlander, Hyvärinen, Almonkari \& Isotalus 2009; Kaipomäki 2011; Koponen 2012). Furthermore, at Finnish university language centres, there are a number of courses in different languages that discuss and talk about various communication competences. What is unclear, however, is the extent to which this content is being acknowledged as explicit course content and communicated to the students. As pointed out by Pullin 
(2010), the communication skills required in the workplace are far more varied than giving formal presentation. Studies have shown that for newly employed graduates informal discussions that enable team work and building and maintaining relationships, are the most frequent and important type of communication (Carnevale, Gainer \& Meltzer 1990; Crossling \& Ward 2002; Zorn \& Violanti 1996).

In order to develop a more coherent foundation for teaching networking competence on university language courses, we first ought to determine exactly what is already being taught in relation to the subject as well as regarding interpersonal skills, knowledge and motivation. Only then will we be able to address the question of how communication and language courses at the university level answer to the needs for networking skills that are such a prominent feature of today's job market.

\section{Challenges and suggestions for future research}

One of the main aims of this paper was to discuss networking as a competence that is possible to acquire. The context is higher education and the focus is on language centre courses that deal with communication skills. We have discussed as an example the situation within Finnish higher education from the viewpoint of the Language Centre of the University of Jyvaskyla, where communication courses are taught not only in foreign languages, but also in Finnish.

We know that networking is considered to be one of the fundamental competences of the future job market (see EK 2011a; Puhakka et al. 2010). We have discussed social networks as being constructed by the interpersonal communication relationships that a person has. Thus, networking requires interpersonal competence that enables a person to develop and maintain his or her interpersonal relationships effectively and appropriately. A part of interpersonal competence is the understanding of the contextual nature of the phenomenon (see Spitzberg 2013). 
While studying the networks of first-year college students, McEwan and Guerrero (2012) found that there is a difference between close and casual friendship networks, and that the maintenance behaviour differed accordingly. This makes us wonder whether there are different skills required for maintaining different kinds of networks such as those consisting of close friends vs. casual friends or those of work colleagues vs. free time acquaintances. In order to enhance university student networking skills that would also be applicable in the ever changing job market in the future, we would also need to know if one needs a different set of skills when networking in different contexts, such as at work and in leisure time, or in a healthcare context versus a business context.

Furthermore, even though Purhonen (2008) looked at networking and cooperation within an intercultural context, there remains a need to investigate different cultural perspectives on networking. For example, members of different cultural groups have knowledge of the meanings of different relationships. When a relationship is being defined as a friendship, a romantic relationship or a professional relationship is dependent on the cultural context. Culture, in a broad sense, can affect the expectations of how one should behave in different kinds of relationships, for example, how different interpersonal relationships are manifested and played out (Fitch \& Sanders 1994; Gudykunst \& Ting-Toomey 1996; Sigman 1998).

What language centres can offer is teaching aimed at language and culture competence as well as interpersonal communication competence. But what is still missing is the knowledge of the particular elements and skills related to interpersonal communication competence in various fields.

In relation to the cultural aspects of social networks, there is also a need for more information on the negative phenomena related to social networks (see Cho, Lee, Stefanone \& Gay 2005). For example, the so-called old-boy networks (hyvä veli-verkostot) in Finland, meaning closely tied, closed networks of businessmen who operate with compromised ethics dealing favours to one another, sometimes leading to corruption, is an example of the ethically dubious phenomena related to social networks that are not consistently discussed or 
studied from the interpersonal communication perspective. Yet Finland is said to be one of the least corrupt countries in the world (Transparency International 2015). In contexts such as these, a deeper overall understanding of the cultural and interpersonal elements of social networks would be welcome.

What is clearly missing is empirical research that examines the development of students' networking competences. In addition to studies trying to determine or explain the factors influencing an individual's learning of networking competences, more qualitative research that offers in-depth information about interpersonal relationships and networking is still needed. For example, Purhonen (2008: n. p.) states the following:

"The literature emphasises the significance of network relationships, but deeper analysis of their creation, management and development is still required. No work has either been done to examine what kinds of social or communicative competencies are needed in the contexts of networking".

In his discussion of interpersonal competence in the healthcare education context, Spitzberg (2013: 132) has also pointed out that models of communication competence "could be translated into some curricular and assessment content". However, like Spitzberg (2013: 132) points out, referring to his own model, "any curricular or assessment translations of this model will require subsequent research to establish the skills that most consistently predict preferred impressions of competence and outcomes".

\section{Conclusion}

Social networks are widely studied phenomena. Different perspectives and theories are being developed, applied and discussed by scholars in many fields and with diverse backgrounds. Communication network theories and groups of theories have provided extensive understanding of the reasons why individuals create, maintain, dissolve and recreate social networks. The advantages and benefits networks provide to individuals and organisations alike have been 
reported in various studies. The focus of this article is from an educational and pedagogical perspective of trying to understand how to enhance an individual's opportunities and abilities to engage in today's global world and ever changing working life.

Adapting network competence as a more explicit part of language centre courses should benefit both students and teachers. In order to do so, one should however have a comprehensive understanding of the processes and nature of networks as social phenomena. Furthermore, the understanding of interpersonal relationships, their development and maintenance would enable teachers and students to grasp the communication, and more specifically, the interpersonal approach to networking.

At the University of Jyväskylä, there is currently an ongoing development of cooperation between different departments and the Language Centre aiming at deeper integration of communication and language studies with subject studies. This integration should also be seen as a possibility to create understanding of the cultural expectations different fields have for networking. In this approach, a deeper understanding of the cultural and contextual expectations and norms of networking in different fields would be available for the students.

There is still a lack, however, of more focused and multidisciplinary research on the possibilities for teaching interpersonal communication networking competence more coherently at higher education units such as language centres. Furthermore, because interpersonal communication competence is, as we see it, the core phenomenon of networking in general, what is needed are empirical studies on the effectiveness of the formal teaching of such competence.

This article provided a brief overview of the concept of social networks from an interpersonal communication perspective. We are ready to hypothesise that networking competences are already being taught on language centre courses. One of the main ideas of this article is to stimulate discussion among language and communication teachers, and to make each of us think about how much interpersonal communication competence we actually teach. We are hoping for 
a broader understanding and awareness of what is being taught and what should be taught to enhance students' networking competence.

\section{References}

Aalto, H.-K. Ahokas, I. \& Kuosa, T. 2008. Yleissivistys ja osaaminen työelämässä 2030 menestyksen eväät tulevaisuudessa. Hankkeen loppuraportti. Tutu-julkaisuja 1/2008. Turku: Tulevaisuuden tutkimuskeskus ja Turun kauppakorkeakoulu.

Ala-Kortesmaa, S. \& Välikoski, T.-R. 2008. Käräjätuomareiden ja syyttäjien käsitykset kuuntelemisesta. In P. Isotalus, M. Gerlander, M. Jäkälä \& T Kokko (eds.), Prologi: puheviestinnän vuosikirja 2008. Prologos, Jyväskylä, 28-50.

Alatarvas, R. 2013. Ihmisten vuorovaikutusverkostojen fysiikkaa [Fysics of human communication networks]. Retrieved from http://www.aka.fi/fi/tietysti/tekniikka/nytpinnalla1/ihmisten-vuorovaikutusverkostojen-fysiikkaa/

Albrecht, T. L. \& Goldsmith, D. J. 2003. Social support, social networks, and health. In T. L. Thompson, A. M. Dorcey, K. I. Miller \& R. Parrott (eds.), Handbook of health communication. Mahwah, New Jersey: Lawrence Erlbaum Associates, 263-284.

Barry, A. 2001. Political machines: governing a technological society. London and New York: Athlone Press.

Borgatti, S. P. \& Halgin, D. S. 2011. On network theory. Organization Science, 22 (5), 1268 1181. doi:10.1287/orsc.1100.0641

Boyd, D. M. \& Ellison, N. B. 2007. Social network sites: definition, history and scholarship. Journal of Computer Mediated Communication, 13 (1), 210-230. doi:10.1111/j.10836101.2007.00393.x

Burleson, B. R. \& Samter, W. 1990. Effects of cognitive complexity on the perceived importance of communication skills in friends. Communication Research, 17 (2), 165182. doi:10.1177/009365090017002002

Burt, R. S. 2004. Structural holes and good ideas. American Journal of Sociology, 110 (2), 349-399. doi:10.1086/421787

Carnevale, A., Gainer, L. J. \& Meltzer, A. S. 1990. Workplace basics: the essential skills employers want. San Francisco, CA: Jossey-Bass.

Castells, M. 1996. The net and the self: working notes for a critical theory of the informational society. Critique of Anthropology, 16 (1), 9-38. doi:10.1177/0308275X9601600103 
Castells, M. 2000. The information age. Vol. 1, the rise of the network society. Oxford and Malden, MA: Blackwell.

Chant, S., Jenkinson, T., Randle, J., Russel, G. \& Webb, C. 2002. Communication skills training in healthcare: a review of the literature. Nurse Education Today, 22 (3), 189-202. doi:10.1054/nedt.2001.0690

Cho, H., Lee, J.-S., Stefanone, M. A. \& Gay, G. 2005. Development of computer-supported collaborative social networks in a distributed learning community. Behaviour \& Information Technology, 24 (6), 435-447. doi:10.1080/01449290500044049

Crossling, G. \& Ward, I. 2002. Oral communication: the workplace needs and uses of business graduate employees. English for Specific Purposes, 21 (1), 41-57. doi:10.1016/S08894906(00)00031-4

Darling, A. L. \& Dannels, D. P. 2003. Practicing engineers talk about the importance of talk: a report on the role of oral communication in the workplace. Communication Education, 52 (1), 1-16. doi:10.1080/03634520302457

EK 2011a. Oivallusraportti [Report of the national career survey]. Retrieved from http://ek.fi/ mita-teemme/innovaatiot-ja-osaaminen/osaaminen-ja-koulutuspolitiikka/oivallus/

EK 2011b. Osaava henkilöstö - menestyvät yritykset. EK:n koulutus- ja työvoimapolittiset linjaukset vuoteen 2015. Retrieved from http://ek.fi/wp-content/uploads/Osaava henkilosto menestyvat yritykset.pdf

FinnSight 2015 [foresight project]. 2006. Tieteen, teknologian ja yhteiskunnan näkymät [The outlook for science, technology, and society]. Helsinki: The Academy of Finland and Tekes.

Fitch, K. L. \& Sanders, R. E. 1994. Culture, communication, and preferences for directness in expression of directives. Communication Theory, 4 (3), 219-245. doi:10.1111/j.1468-2885.1994.tb00091.x

Frankham, J. 2006. Network utopias and alternative entanglements for educational research and practice. Journal of Education Policy, 21 (6), 661-677. doi:10.1080/02680930600969191

Frymier, A. B. \& Houser, M. L. 2000. The teacher-student relationship as an interpersonal relationship.CommunicationEducation, 49(3),207-219.doi:10.1080/03634520009379209

Gaboury, J. 1999. 30 ways to be a better IE. IIE Solutions, 31 (1), 28-35.

Gerlander, M., Hyvärinen, M-L., Almonkari, M. \& Isotalus, P. 2009. Mitä ja miten puheviestinnän opintojaksoilla opetetaan? In M. Almonkari \& P. Isotalus (eds.), Akateeminen puheviestintä. Kuinka opettaa puheviestintää yliopisto-opiskelijoille? Helsinki: Finn Lectura, 8-24. 
Gielen, P. A., Hoeve, A. \& Nieuwenhuis, L. F. M. 2003. Learning entrepreneurs: learning and innovation in small companies. European Educational Research Journal, 2 (1), 90-106. doi:10.2304/eerj.2003.2.1.13

Gould, R. V. 2003. Uses of network tools in comparative historical research. In J. Mahoney \& D. Rueschemeyer (eds.), Comparative historical analysis in the social sciences. Cambridge: Cambridge University Press, 241-269. doi:10.1017/cbo9780511803963.008

Gray, F. E. 2010. Specific oral communication skills desired in new accountancy graduates. Business Communication Quarterly, 73 (1), 40-67. doi:10.1177/1080569909356350

Greene, J. O. 2003. Models of adult communication skill acquisition: practice and the course of performance improvement. In J. O. Greene \& B. R. Burleson (eds.), Handbook of communication and social interaction skills. Mahwah: Lawrence Erlbaum, 51-91.

Gudykunst, W. B. \& Ting-Toomey, S. 1996. Communication in personal relationships across cultures. An introduction. In W.B. Gudykunst, S. Ting-Toomey \& T. Nishida (eds.), Communication in personal relationships across cultures. Thousand Oaks, CA: Sage, $3-16$.

Hardy, C., Phillips, N. G. \& Lawrence, T. B. 2003. Resources, knowledge and influence: the organizational effects in intraorganizational collaboration. Journal of Management Studies, 40 (2), 321-347. doi:10.1111/1467-6486.00342

Hargie, O., Boohan, M., McCoy, M. \& Murphy, P. 2010. Current trends in communication skills training in UK schools of medicine. Medical Teacher, 32 (5), 385-391. doi:10.3109/01421590903394603

Hargie, O. \& Dickson, D. 2004. Skilled interpersonal communication: research, theory and practice (4th ed.). London: Routledge.

Hargie, C. T. C \& Tourish, D. 1997. Relational communication. In O. Hargie (ed.), The Handbook of communication skills (2nd ed.). London: Routledge, 358-382.

Himanen, P. 2004. (toim.) Globaali tietoyhteiskunta. Kehityssuuntia Piilaaksosta Singaporeen. Helsinki: Tekes, Teknologiakatsaus 155/2004.

Huotari, M.-L., Hurme, P. \& Valkonen, T. 2005. Viestinnästä tietoon: tiedon luominen työyhteisössä. Helsinki, WSOY.

Hyvärinen, M-L. 2011. Alakohtainen vuorovaikutus farmasiassa. Acta Universitatis Tamperensis 1604. Tampere: Tampereen yliopisto.

Isotalus, P. 2006. Virkaanastujaisesitelmä: Puheviestintä tietona. In T-R. Välikoski, E. Kostiainen, E. Kyllönen \& L. Mikkola (eds.), Prologi. Puheviestinnän vuosikirja 2006. Jyväskylä: Prologos ry. 
Isotalus, P. \& Mäki, E. 2009. Tiedon rooli puheviestinnän opetuksessa? In M. Almonkari \& P. Isotalus (eds.), Akateeminen puheviestintä. Kuinka opettaa puheviestintää yliopistoopiskelijoille? Helsinki: Finn Lectura.

Kaipomäki, E. 2011. Suomalaisten yliopistojen kieli- ja viestintäopintoihin kuuluvan puheviestinnän opetuksen nykytila ja haasteet. Retrieved from http://urn.fi/ urn:nbn:fi:uta-1-22019

Katz, N., Lazer, D., Arrow, H. \& Contractor, N. 2004. Network theory and small groups. Small Group Research, 35 (3), 307-332. doi:10.1177/1046496404264941

Knox, H., Savage, M. \& Harvey, P. 2006. Social networks and the study of relations: networks as method, metaphor and form. Economy and Society, 35 (1), 113-140. doi:10.1080/03085140500465899

Kokkonen, L. 2010. Pakolaisten vuorovaikutussuhteet: Keski-Suomeen muuttaneiden pakolaisten kokemuksia vuorovaikutussuhteistaan ja kiinnittymisestään uuteen sosiaaliseen ympäristöön [ Interpersonal relationships of refugees in Central Finland]. Jyvaskyla Studeis in Humanities, 143. University of Jyvaskyla.

Koponen, J. 2012. Kokemukselliset oppimismenetelmät lääketieteen opiskelijoiden vuorovaikutuskoulutuksessa [Professionally-oriented communication education in the field of medicine]. Acta Universitatis Tamperensis 1734. Tampere: Tampereen yliopisto.

Kostiainen, E. 2003. Viestintä ammattiosaamisen ulottuvuutena [Communication as a dimension of vocational competence]. Jyväskylä studies in humanities 1. University of Jyvaskyla.

Laajalahti, A. 2007. The development of interpersonal communication competence at work. In N. Carpentier, P. Pruulmann-Vengerfeldt, K. Nordenstreng, M. Hartmann, P. Vihalemm, B. Cammaerts \& H. Nieminen (eds.), Media technologies and democracy in an enlarged Europe: the intellectual work of the 2007 European media and communication doctoral summer school. The researching and teaching communication series (3). Tartu: Tartu University Press, 335-345.

Laajalahti, A. 2014. Vuorovaikutusosaaminen ja sen kehittyminen tutkijoiden työssä [Interpersonal communication competence and its development in the work of researchers]. Jyväskylä studies in Humanities, 225. Jyväskylä: Jyväskylä University Press.

Lakey, S. G. \& Canary, D. J. 2002. Actor goal achievement and sensitivity to partner as critical factors in understanding interpersonal communication competence and conflict strategies. Communication Monographs, 69 (3), 217-235. doi:10.1080/03637750216542 
Lang, J. D., Cruse, S., McVey, F. D. \& McMasters, J. 1999. Industry expectations of new engineers: A survey to assist curriculum designers. Journal of Engineering Education, 88 (1), 43-51. doi:10.1002/j.2168-9830.1999.tb00410.x

Leskinen, R. 2011. A longitudinal case study of an entrepreneurial networking process. Helsinki: Aalto University. Retrieved from http://epub.lib.aalto.fi/pdf/diss/Aalto DD_2011_032.pdf

Linturi, H. 2007. Matkalla sivistysyhteiskuntaan. Opetusministeriön sivistysbarometri 19972017. Väliraportti 2007. Metodix \& Internetix.

Littlejohn, S. W. 2002. Theories of human communication (7th ed.). Belmont: Wadsworth.

McEwan, B. \& Guerrero, L. K. 2012. Maintenance behavior and relationship quality as predictors of perceived availability of resources in newly formed college friendship networks. Communication Studies, 63 (4), 421-440. doi:10.1080/10510974.2011.639 433

Merriam, S. B. \& Clark, C. 1993. Learning from life experience. What makes it significant? International Journal of Lifelong Education, 12 (2), 129-138. doi:10.1080/0260137930120205

Mitchell, R. E. \& Trickett, E. J. 1980. Task force report: Social networks as mediators of social support. An analysis of the effect and determinants of social networks. Community Mental Health Journal, 16 (1), 27-44. doi:10.1007/BF00780665

Mittilä, T. 2006. Verkosto-osaaminen - liiketoimintaosaamisen uusi mantra. Retrieved from http://www.edu.fi/perusopetus/historia_yhteiskuntaoppi/liiketoimintaosaaminen

Monge, P. R. \& Contractor, N. 2003. Theories of communication networks. New York: Oxford University Press.

Moolenaar, N. M. \& Sleegers, P. J. C. 2010. Social networks, trust, and innovation. How social relationships support trust and innovative climates in Dutch schools. In A. Daly (ed.), Social Network Theory and Educational Change. Cambridge, MA: Harvard University Press, 97-114.

Morreale, S. P., Osbon, M. M. \& Pearson, J. D. 2000. Why communication is important: a rationale for the centrality of the study of communication. Journal of the Association for Communication Administration, 29, 1-25.

Neuliep, J. W. 1996. Human communication theory. Applications \& case studies. Boston: Allyn and Bacon.

Obstfeld, D. 2005. Social networks, the tertius iungens orientation, and involvement in innovation. Admin. Sci. Quart, 50 (1), 100-130. 
Perry-Smith, J. E. \& Shalley, C. E. 2003. The social side of creativity: a static and dynamic social network perspective. Academy of Management Review, 28 (1), 89-106.

Puhakka, A., Rautopuro, J. \& Tuominen, V. 2010. Employability and Finnish university graduates. European Educational Research Journal, 9 (1), 45-55. doi:10.2304/ eerj.2010.9.1.45

Pullin, P. 2010. Small talk, rapport, and international communicative competence: lessons to learn from BELF. International Journal of Business Communication, 47 (4), 455-476. doi:10.1177/0021943610377307

Purhonen, P. 2008. SME internationalization as a challenge to interpersonal communication competence: an analysis of interpersonal communication competence in networking and collaboration. Journal of Intercultural Communication, 18. Retrieved from http://www. immi.se/intercultural/nr18/purhonen.htm

Purhonen, P. 2012. Interpersonal communication competence and collaborative interaction in SME internationalization. Jyväskylä studies in humanities 178. Jyväskylä: University of Jyväskylä.

Purhonen, P. \& Valkonen, T. 2013. Measuring interpersonal communication competence in SME internationalization. Journal of Intercultural Communication, 33. Retrieved from http://immi.se/intercultural

Pyöriä, P. 2006. Understanding work in the age of information. Finland in Focus. Tampere: Tampere University Press.

Riles, A. 2000. The network inside out. Ann Arbor: University of Michigan Press.

Ritter, T. \& Gemünden, H. G. 2003. Network competence: its impact on innovation success and its antecedents. Journal of Business research, 56 (9), 745-755. doi:10.1016/S01482963(01)00259-4

Rogers, E. M. \& Kincaid, D. L. 1981. Communication networks: toward a new paradigm for research. New York: Free Press.

Rouhiainen-Neuenhäuserer, M. 2009. Johtajan vuorovaikutusosaaminen ja sen kehittyminen : johtamisen viestintähaasteet tietoperustaisessa organisaatiossa [The interpersonal communication competence of leaders and its development: leadership communication challenges in a knowledge-based organization]. Jyväskylä studies in humanities 128. Jyväskylän University.

Segrin, C. \& Givertz, M. 2003. Methods of social skills training and development. In J. O. Greene \& B. R. Burleson (eds.), Handbook of communication and social interaction skills. Mahwah: Lawrence Erlbaum, 135-176 
Sigman, S. J. 1998. Relationships and communication: A social communication and strongly consequential view. In R. L. Conville \& L. E. Rogers (eds.), The meaning of "relationship" in interpersonal communication. Westport, Connecticut: Praeger, 41-82.

Sparrowe, R. T., Liden, R. C., Wayne, S. J. \& Kraimer, M. L. 2001. Social networks and the performance of individuals and groups. Academy of Management Journal, 44 (2), 316-325. doi:10.2307/3069458

Spitzberg, B. H. 2000. What is good communication? Journal of the Association for Communication Administration, 29, 103-119.

Spitzberg, B. H. 2003. Methods of skill assessment. In J. O. Greene \& B. R. Burleson (eds.), Handbook of communication and social interaction skills. Mahwah, NJ: Lawrence Erlbaum, 93-134.

Spitzberg, B. H. 2013. (Re)Introducing communication competence to the health professions. Journal of Public Health Research, 2 (23), 126-135. doi:10.4081/jphr.2013.e23

Spitzberg, B. H. \& Cupach, W. R. 1984. Interpersonal communication competence. Beverly Hills, CA: Sage.

Thornton, S. C, Henneberg, S. C. \& Naudé, P. 2013. Understanding types of organizational networking behaviors in the UK manufacturing sector. Industrial Marketing Management, 42 (7), 1154-1166. doi:10.1016/j.indmarman.2013.06.005

Transparency International 2015. Retrieved from https://www.transparency.org/cpi2014/ results

Trevillion, S. 2000. Social work, social networks and network knowledge. British Journal of Social Work, 30 (4), 505-517. doi:10.1093/bjsw/30.4.505

Valkonen, T. 2003. Puheviestinnän arviointi. Näkökulmia lukiolaisten esiintymis- ja ryhmätaitoihin [Assessing speech communication skills. perspectives on presentation and group communication skills among upper secondary school students]. University of Jyväskylä. Jyväskylä Studies in Humanities 7.

Wellman, B. 2007. Editorial. The network is personal: introduction to a special issue of Social Networks. Social Networks, 29 (3), 349-356. doi:10.1016/j.socnet.2007.01.006

Wilmot, W. W. 1996. The relational perspective. In K. M. Galvin \& P. J. Cooper (eds.), Making connections. Readings in relational communication (4th ed). Los Angeles, CA: Roxbury, 16-24.

Zorn, T. E. \& Violanti, M. T. 1996. Communication abilities and individual achievement in organizations. Management Communication Quarterly, 10 (2), 139-167. doi:10.1177/0893318996010002001 


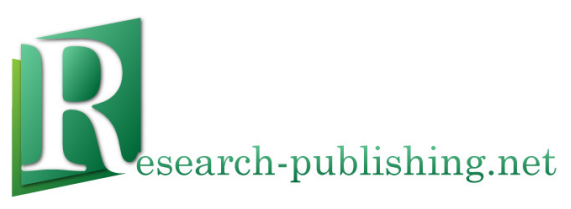

Published by Research-publishing.net, not-for-profit association Dublin, Ireland; Voillans, France, info@research-publishing.net

(C) 2015 by Research-publishing.net (collective work)

Each author retains their own copyright

Voices of pedagogical development - Expanding, enhancing and exploring higher education language learning Edited by Juha Jalkanen, Elina Jokinen, \& Peppi Taalas

Rights: All articles in this collection are published under the Attribution-NonCommercial -NoDerivatives 4.0 International (CC BY-NC-ND 4.0) licence. Under this licence, the contents are freely available online (as PDF files) for anybody to read, download, copy, and redistribute provided that the author(s), editorial team, and publisher are properly cited. Commercial use and derivative works are, however, not permitted.

\section{()ㅛ $\Theta \Theta$}

Disclaimer: Research-publishing.net does not take any responsibility for the content of the pages written by the authors of this book. The authors have recognised that the work described was not published before, or that it is not under consideration for publication elsewhere. While the information in this book are believed to be true and accurate on the date of its going to press, neither the editorial team, nor the publisher can accept any legal responsibility for any errors or omissions that may be made. The publisher makes no warranty, expressed or implied, with respect to the material contained herein. While Research-publishing.net is committed to publishing works of integrity, the words are the authors' alone.

Trademark notice: Product or corporate names may be trademarks or registered trademarks, and are used only for identification and explanation without intent to infringe.

Copyrighted material: Every effort has been made by the editorial team to trace copyright holders and to obtain their permission for the use of copyrighted material in this book. In the event of errors or omissions, please notify the publisher of any corrections that will need to be incorporated in future editions of this book.

Typeset by Research-publishing.net

Cover design by (C) Antti Myöhänen

ISBN13: 978-1-908416-25-4 (Paperback - Print on demand, black and white)

Print on demand technology is a high-quality, innovative and ecological printing method, with which the book is never 'out of stock' or 'out of print'.

ISBN13: 978-1-908416-26-1 (Ebook, PDF, colour)

ISBN13: 978-1-908416-27-8 (Ebook, EPUB, colour)

Legal deposit, Ireland: The National Library of Ireland, The Library of Trinity College, The Library of the University of Limerick, The Library of Dublin City University, The Library of NUI Cork, The Library of NUI Maynooth, The Library of University College Dublin, The Library of NUI Galway.

Legal deposit, United Kingdom: The British Library.

British Library Cataloguing-in-Publication Data.

A cataloguing record for this book is available from the British Library.

Legal deposit, France: Bibliothèque Nationale de France - Dépôt légal: septembre 2015. 